\begin{tabular}{l} 
2. To: (Receiving organization) \\
Distribution \\
\hline 5. Proj./Prog./Dept./Div.: \\
Privatization Infrastructure
\end{tabular}

8. Originator Remarks:

For approval and release

11. Receiver Remarks:

11A. Design Basel ine Document?

3. From: (Originating Organization)
P. S. Schaus, LMHC
6. Design Authority/ Design Agent/Cog.
Engr.:

4. Related EOT No.:
NA
7. Purchase Order No.:
NA

9. Equip./Component No.:

NA

10. System/Bldg./Facility:

NA

12. Major Assm. Dwg. No.:

NA

13. Permit/Permit Application No.: NA

14. Required Response Date:

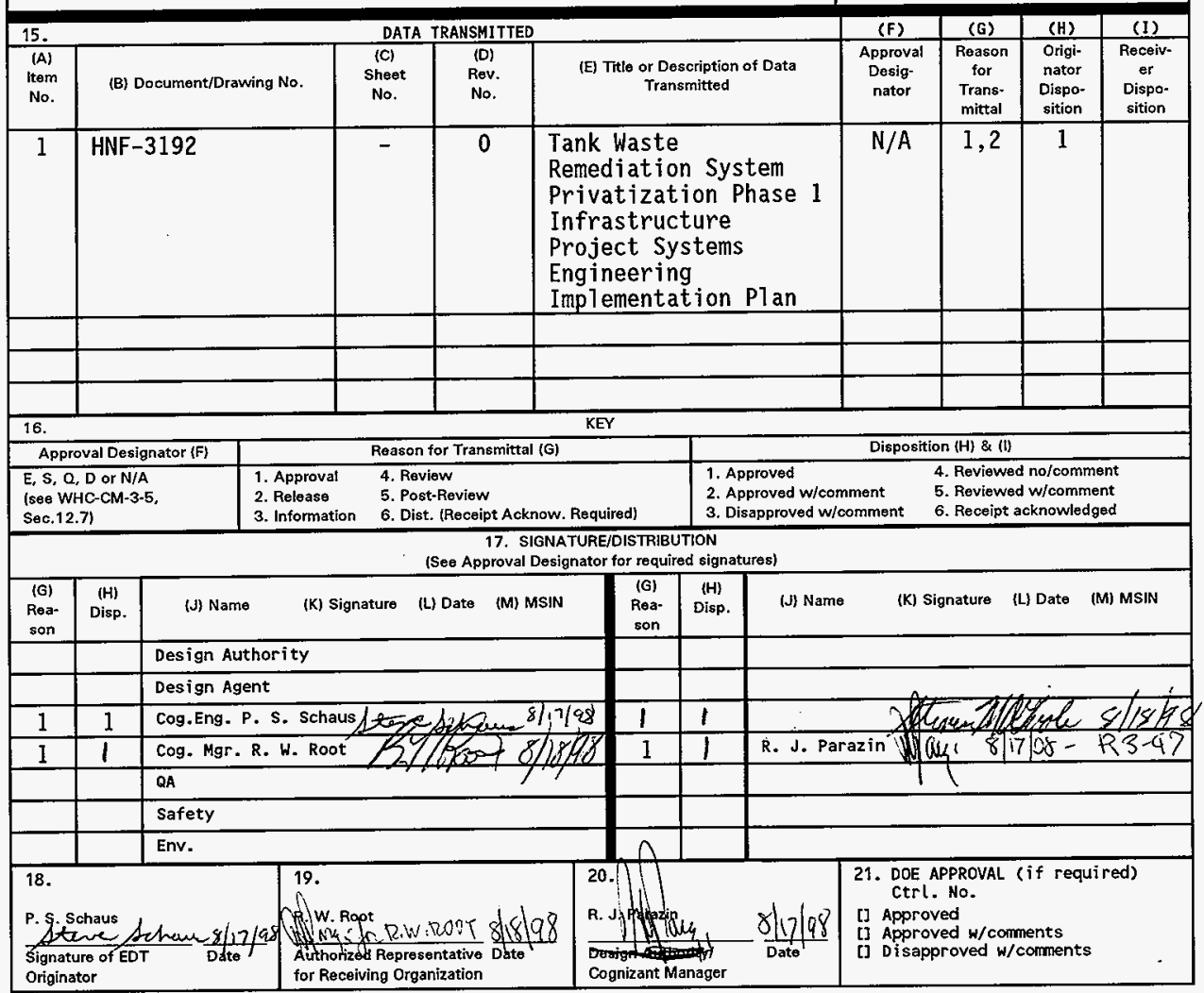




\section{Tank Waste Remediation System Privatization Phase 1 Infrastructure Project Systems Engineering Implementation Plan}

P. S. Schaus, R. J. Parazin (NHC), and B. J. Hendel (TRW)

Lockheed Martin Hanford Corporation, Richland, WA 99352

U.S. Department of Energy Contract DE-AC06-96RL13200

$\begin{array}{llll}\text { EDT/ECN: } & 161498 & \text { UC: } 721, U C-2000 & \\ \text { Org Code: } & 73500 & \text { Charge Code: D6327 } & \text { HJ260500 } \\ \text { B\&R Code: } & \text { EW3130010 } & \text { Tota1 Pages: } 35 & \end{array}$

Key Words: TWRS, systems engineering, W-519

Abstract: This Systems Engineering Implementation Plan (SEIP) describes the processes, products, and organizational responsibilities implemented by Project $W-519$ to further define how the project's mission, defined initially by the Tank Waste Remediation System Phase I Privatization Infrastructure Project W-503 Mission Analysis Report (Hoertkorn 1997), will be accomplished using guidance provided by the Tank Waste Remediation System Systems Engineering Management Plan (SEMP) (Peck 1998). This document describes the implementation plans for moving from a stated mission to an executable cost, schedule, and technical baseline and to help ensure its successful completion of those baselines.

TRADEMARK DISCLAIMER. Reference herein to any specific comercial product, process, or service by trade name, trademark, manufacturer, or otherwise, does not necessarily constitute or imply its endorsement, recommendation, or favoring by the United States Government or any agency thereof or its contractors or subcontractors.

Printed in the United States of America. To obtain copies of this document, contact: Document control services, P.0. Box 950, Mailstop H6-08, Richland WA 99352, Phone (509) 372-2420; Fax (509) 376-4989.
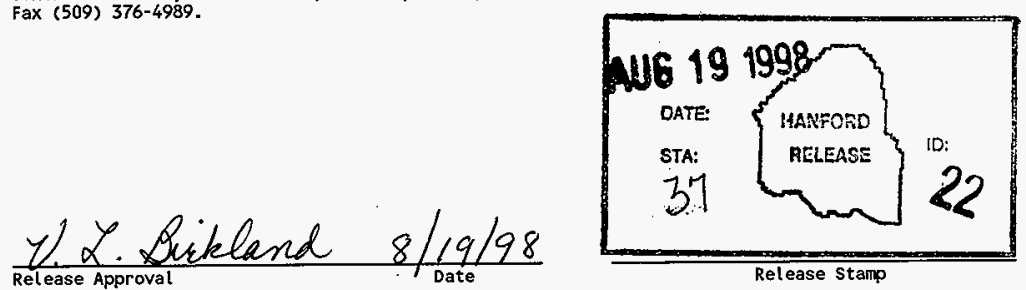

Approved for Public Release 
HNF-3192

Revision 0

\title{
TANK WASTE REMEDIATION SYSTEM PRIVATIZATION PHASE 1 \\ INFRASTRUCTURE PROJECT SYSTEMS ENGINEERING IMPLEMENTATION PLAN
}

\author{
August 1998 \\ P. S. Schaus \\ Lockheed Martin Hanford Corporation \\ Richland, Washington
}

R. J. Parazin

Numatec Hanford Corporation

Richland, Washington

B. J. Hendel

TRW Environmental Systems

Richland, Washington

Prepared for:

U.S. Department of Energy

Richland, Washington 
HNF-3192

Revision 0

This page intentionally left blank. 
HNF-3192

Revision 0

CONTENTS

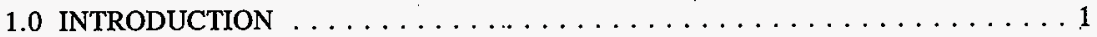

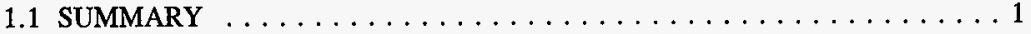

1.2 SCOPE AND APPLICABILITY $\ldots \ldots \ldots \ldots \ldots \ldots \ldots \ldots \ldots \ldots$

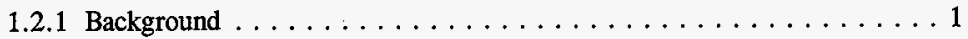

1.2 .2 Project Risks . . . . . . . . . . . . . . . . . . 3

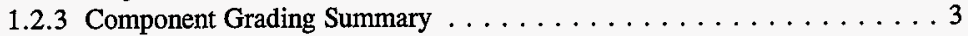

1.2.4 Interface with Other Planning Documents . . . . . . . . . 4

2.0 SYSTEMS ENGINEERING MANAGEMENT PROCESSES $\ldots \ldots \ldots \ldots \ldots \ldots 5$

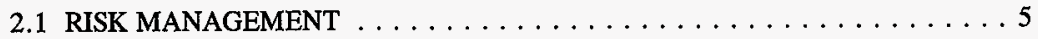

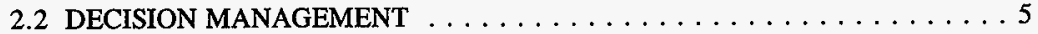

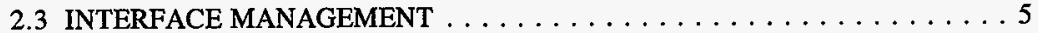

2.4 CONFIGURATION MANAGEMENT $\ldots \ldots \ldots \ldots \ldots \ldots \ldots \ldots \ldots$

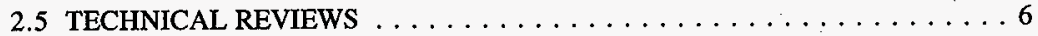

2.6 SYSTEMS ENGINEERING MANAGEMENT PROCESS ROLES AND RESPONSIBILITIES $\ldots \ldots \ldots \ldots \ldots \ldots \ldots \ldots \ldots \ldots \ldots \ldots \ldots \ldots$

3.0 SYSTEMS ENGINEERING PROCESS AND PRODUCTS $\ldots \ldots \ldots \ldots \ldots \ldots 7$

3.1 SYSTEMS ENGINEERING PROCESS $\ldots \ldots \ldots \ldots \ldots \ldots \ldots \ldots \ldots$

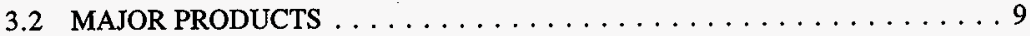

3.3 ROLES AND RESPONSIBILITIES $\ldots \ldots \ldots \ldots \ldots \ldots \ldots \ldots \ldots \ldots$

4.0 REFERENCES $\ldots \ldots \ldots \ldots \ldots \ldots \ldots \ldots \ldots \ldots \ldots \ldots \ldots \ldots$

FIGURE

3-1. Project System Engineering Process $\ldots \ldots \ldots \ldots \ldots \ldots \ldots \ldots$

APPENDIXES

A - W-519 SYSTEMS ENGINEERING GRADED RISK AREAS/ COMPLEXITY FACTORS $\ldots \ldots \ldots \ldots \ldots \ldots \ldots \ldots$ A 1

B - GRADING OF MAJOR PRODUCTS BASED ON RISK/COMPLEXITY

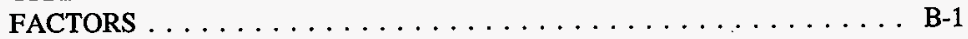

C - INFRASTRUCTURE PROGRAM RISK MANAGEMENT IMPLEMENTATION PLAN $\ldots \ldots \ldots \ldots \ldots \ldots \ldots \ldots \ldots \ldots$ - 1 
HNF-3192

Revision 0

\section{LIST OF TERMS}

$\begin{array}{ll}\text { CD } & \text { Critical Decision } \\ \text { CEIS } & \text { Cost estimating input sheet } \\ \text { DOE } & \text { U.S. Department of Energy } \\ \text { DRD } & \text { Design requirements document } \\ \text { FSAR } & \text { Facility Safety Analysis Report } \\ \text { HSTD } & \text { Hanford Site Technical Database } \\ \text { ICD } & \text { Interface control document/drawing } \\ \text { LMHC } & \text { Lockheed Martin Hanford Corporation } \\ \text { MYPP } & \text { Multi-year Program Plan } \\ \text { O\&M } & \text { Operations and Maintenance } \\ \text { PC } & \text { Privatization Contractor } \\ \text { PEP } & \text { Project Execution Plan } \\ \text { PHMC } & \text { Project Hanford Management Contract } \\ \text { ROD } & \text { Record of Decision } \\ \text { ROI } & \text { Return on Investment } \\ \text { SE } & \text { Systems Engineering } \\ \text { SEIP } & \text { Systems Engineering Implementation Plan } \\ \text { SEMP } & \text { Systems Engineering Management Plan } \\ \text { SSC } & \text { Systems, structures, and components } \\ \text { TBR } & \text { Technical Basis Review } \\ \text { TWR } & \text { Tank Waste Retrieval } \\ \text { TWRS } & \text { Tank Waste Remediation System }\end{array}$


HNF-3192

Revision 0

\section{TANK WASTE REMEDIATION SYSTEM PRIVATIZATION PHASE 1 INFRASTRUCTURE PROJECT SYSTEMS ENGINEERING IMPLEMENTATION PLAN}

\subsection{INTRODUCTION}

The U.S. Department of Energy (DOE), as part of the strategy to privatize the immobilization of the Hanford tank waste, will provide electricity, raw and potable water, a prepared site and roads and will accept liquid effluents from the privatization contractor. Privatization Phase 1 Infrastructure Project W-519 was chartered with the mission to define, design, and build the systems to support the private contractor infrastructure needs for construction and operation of the Privatization Contractor's (PC) facilities. After acceptance, the systems will be turned over to the Site Infrastructure and Waste Management contractors for operations.

\subsection{SUMMARY}

This Systems Engineering Implementation Plan (SEIP) describes the processes, products, and organizational responsibilities implemented by Project W-519 to further define how the project's mission, defined initially by the Tank Waste Remediation System Phase 1 Privatization Infrastructure Project W-503 Mission Analysis Report (Hoertkorn 1997), will be accomplished using guidance provided by the Tank Waste Remediation System Systems Engineering Management Plan (SEMP) (Peck 1998). This document describes the implementation plans for moving from a stated mission to an executable cost, schedule, and technical baseline and to help ensure its successful completion of those baselines.

\subsection{SCOPE AND APPLICABILITY}

This SEIP applies to all Project W-519 technical activities, including subcontracts, throughout the project life cycle from conceptual design through construction of facilities and systems and turnover to the Site Infrastructure and Waste Management contractors. This SEIP communicates the project specific planning for implementing systems engineering as defined in the TWRS SEMP (Peck 1998). Where existing plans and procedures exist, those documents are referenced herein.

\subsubsection{Background}

Project W-519 will provide site and road development, electrical power, water, and liquid effluents transfer systems in support of the Tank Waste Remediation System (TWRS) 
Phase 1 Privatization contract. Additional details of the conceptual design and design requirements are provided in the Conceptual Design Reports and Design Requirements Documents listed in the Tank Waste Remediation System Privatization Phase I Infrastructure Project W-519 Project Execution Plan (Parazin 1998a) and as referenced herein.

Project W-519 has completed conceptual design and the project is progressing to Critical Decision 2 (CD 2), approval of the technical baseline for W-519 systems. The Critical Decisions (CD 2 through 4) will be conducted in accordance with DOE Order 430.1 Life Cycle Asset Management, Good Practice Guide, Critical Decision Criteria, GPG-FM-002 (DOE 1996). Immediately after CD 2, the Electrical System will be subjected to an incremental Critical Decision (CD 3A) to support the start of construction of the Electrical Power System. The CD 3 milestone (CD 3B) for systems other than the Electrical Power System (i.e., Water System, Liquid Effluent System, and Site Development) is planned for February 1999. The Project is awaiting validation of the technical baseline from DOE based on Privatization contracts.

The technical baseline for Phase 1 is currently documented in Design Requirement Documents (DRDs) for each of four system elements (Privatization Electrical Power Systems, Privatization Site Development, Privatization Liquid Effluent System, and Privatization Raw and Potable Water Supply System) and Interface Control Documents (ICD), defining the functional interfaces as listed below:

\section{Design Requirement Documents}

- Design Requirements Document for Phase I, Privatization Electrical Power Systems (Singh 1997)

- Design Requirements Document for Phase I, Privatization Site Development (Shord 1997)

- Design Requirements Document for Phase I, Privatization Raw and Potable Water Supply System (Parazin 1996a)

- Design Requirements Document for Phase I, Privatization Liquid Effluent Systems (Parazin 1996b)

\section{Interface Control Documents}

- Interface Control Document for TWRS Privatization Phase I Infrastructure Support Project W-519 (Parazin 1998b)

- Tank Waste Remediation System Privatization Project Interface Control Document (BNFL 1998)

The technical baseline noted above will be expanded following CD 2 to include design 
drawings, ICDs (drawings), procurement/construction specifications, site characterization report, and safety documentation.

\subsubsection{Project Risks}

The W-519 Project risks have been identified and were documented in Attachment A of the Risk Analysis Management Report (Schaus 1998) in accordance with the TWRS Risk Management Procedure (LMHC 1997). It was determined that the W-519 Project does not resolve any TWRS Project risks (i.e., no 'critical' risks have been identified). The W-519 Project risks are primarily programmatic and relate to the timely execution of the Privatization Contract, thereby preventing delays in validation of the W-519 technical baseline, and receipt of W-519's CD 2 approvals. The risk management processes used to derive the W-519 risks are described in Section 2.1 of this document.

\subsubsection{Component Grading Summary}

Guidance for grading W-519 systems, structures, and components, (SSC) to determine the appropriate level of rigor for systems engineering implementation and associated products was provided by the Draft TWRS Systems Engineering Grading Guidelines, HNF-IP-0842. The three systems (i.e., Electrical System, Liquid Effluent System, and Raw and Potable Water Supply System) were evaluated with the recommended component risk areas/complexity factors and the findings summarized in Appendix A. Note that the components needed for site preparation (i.e., grading and removal of an existing soil pile) are not developmental items and therefore were not subjected to the grading process.

The W-519 SSCs were rated "high", "moderate", or "low" for each Risk Areas/Complexity factor using the descriptions in Table 5.1 of the TWRS Systems Engineering Grading Guidelines and a simple arithmetic average performed on the individual results to achieve an Overall Complexity rating. The evaluation resulted in a "low" overall ranking for each of the SSCs. Given this ranking, the SSC Systems Engineering (SE) Level will be either SE-2 or SE-3 depending on the project scope. As W-519 SSCs are new construction, the SE-2 category is the applicable category. SE-3 applies to projects that are "changeout-in-kind" or a form, fit, and function replacement.

In summary, the W-519 systems were categorized as follows;

System

Privatization Electrical Power Systems

Privatization Liquid Effluent System

Privatization Raw and Potable Water Supply System
Classification

SE-2

SE-2

SE-2

From this categorization, the recommended processes and products were tailored for each SSC using Table 5.2 of the TWRS Systems Engineering Grading Guidelines. The resulting 
HNF-3192

Revision 0

planned product list for the W-519 SSCs is included in Appendix B.

\subsubsection{Interface with Other Planning Documents}

This SEIP is intended to delineate the systems engineering aspects of the project and support the Tank Waste Remediation System Privatization Phase I Infrastructure Project W-519 Project Execution Plan (PEP) (Parazin 1998a). This SEIP uses the guidelines for systems engineering described in the TWRS SEMP (Peck 1998). 


\subsection{SYSTEMS ENGINEERING MANAGEMENT PROCESSES}

\subsection{RISK MANAGEMENT}

Risk Management for Project W-519 is performed per the guidelines of the TWRS Risk Management Procedure (LMHC 1997). Appendix C provides the Privatization Infrastructure Risk Implementation Plan that describes the activities for identifying, analyzing, documenting, mitigating and monitoring project risks. The TWRS Privatization Infrastructure risk management list provides a listing of project-specific risk information.

\subsection{DECISION MANAGEMENT}

Project W-519 has implemented a simplified Decision Management process as referenced in the TWRS SEMP (Peck 1998), Section 2.3.4 consistent with the Decision Management Procedure (LMHC 1997). Technical decisions of major program importance are documented and the responsible manager and/or decision maker is assigned. The overall compilation of major TWRS Project decisions including the status of those for Project W-519 are documented in the TWRS Technical Decision Status Summary (Zimmerman 1997). Currently, for Project W-519, no outstanding decisions exist, nor are new project level decisions expected. If new decisions are identified, they will be planned, framed, analyzed, closed and documented in accordance with the Decision Management Procedure.

\subsection{INTERFACE MANAGEMENT}

Preparation and maintenance of ICDs are described in the W-519 PEP, Section 5.2.2, which references the Project Hanford Management Contract (PHMC) procedure HNF-PRO-243, and the Interface Management Procedure (LMHC 1997). Note that the discussion in the PEP on interfaces deals mostly with functional interfaces as opposed to physical interfaces (i.e., electrical/mechanical). Physical interfaces will be defined using ICDs as part of the definitive design process, following CD 2. ICDs for physical interfaces are reviewed, and approved using the Configuration Management processes of Section 2.4.

Agreements that document functional and organizational interfaces with other TWRS projects are recorded as Memoranda of Agreement. Agreements between LMHC and other PHMC contractors are recorded as contract modifications and incorporated into the Fluor Daniel Hanford contract guidance for future work planning.

\subsection{CONFIGURATION MANAGEMENT}

Configuration management for Project W-519 is described in the TWRS Privatization Infrastructure Project Configuration Management Implementation Plan (Parazin 1998c). The 
HNF-3192

Revision 0

guidance for this plan was provided by the TWRS Configuration Management Plan (Vann 1998). The TWRS Privatization Infrastructure Project Configuration Management

Implementation Plan (Parazin 1998c) describes the processes to be used to control the technical, cost, and schedule baselines and include related activities by subcontractors or interfacing projects that support the identified processes.

\subsection{TECHNICAL REVIEWS}

Technical reviews are conducted per the TWRS SEMP (Peck 1998), Section 2.3.6. These involve reviews to support the Critical Decision (CD) milestones as defined in DOE Order 430.1 Good Practice Guide, Critical Decision Criteria (DOE 1996). As stated in Section 1.2 of this document, the next review for Project W-519 is CD 2, where the authorization to proceed with definitive design is expected. The following documents are currently in work to support the CD 2 milestone:

a) SEIP (this document)

b) Configuration Management Implementation Plan

c) Risk Management Implementation Plan (Appendix C of this document)

d) Project Execution Plan

e) Acquisition Plan.

Internal reviews during the definitive design phase (beyond $C D$ 2) will be conducted twice: when the design is 30 percent and 90 percent complete. The next external review following $\mathrm{CD} 2$ will be $\mathrm{CD} 3$, where approvals will be completed for the start of construction. Additionally, an Operational Startup Review will be held as part of CD 4. See the Project W-519 PEP (Parazin 1998a), Section 2.3, for additional details regarding planned reviews.

\subsection{SYSTEMS ENGINEERING MANAGEMENT PROCESS ROLES AND RESPONSIBILITIES}

Roles and responsibilities for the systems engineering management processes are defined in the Tank Waste Remediation System Privatization Phase I Infrastructure Project W-519 Project Execution Plan (Parazin 1998a) Table 3-1. 


\subsection{SYSTEMS ENGINEERING PROCESS AND PRODUCTS}

\subsection{SYSTEMS ENGINEERING PROCESS}

The project systems engineering process, as illustrated in Figure 3-1, is described below. This process is consistent with the TWRS SEMP (Peck 1998) and the DOE's Tank Waste Remediation System (TWRS) Systems Engineering Management Policy (Kinzer 1997).

Project W-519 developed its initial technical baseline using functional and requirements analysis and documented the results in Design Requirements Documents (DRDs). Currently traceability data for the DRD requirements is being maintained informally by the document authors. The project performed alternative evaluations and documented the results in Engineering Studies, which are equivalent to Alternative Generation and Analysis documents.

The project has completed its conceptual design activities, and has approved Conceptual Design Reports. Based on the results of the conceptual design, W-519 updated the DRDs and developed an inter-project ICD to coordinate the interfaces between the W-519 systems and systems being installed by other TWRS projects.

The project will migrate the functions, requirements, and interface data into the Hanford Site Technical Database (HSTD), along with requirements traceability information. The HSTD will generate Level 2 specifications similar in form, fit and function to the DRD to replace the existing documents, but will have full requirements traceability and integration with the rest of the Hanford and TWRS major facilities.

After $\mathrm{CD} 2$ the project will perform detailed design activities including specialty engineering analysis for the raw and potable water system, the liquid effluent system, and for site preparation activities. The electrical system will be procured from a commercial vendor using a single contract for design and construction services. Design reviews will be conducted at the 30 and 90 percent complete milestones including the electrical system.

Design will be verified against the requirements using the methods documented in Section 4.0 of the specifications before authorizing start of construction (CD 3). After construction is complete, system performance will be verified by acceptance and operational tests. The project will provide for the development of operations and maintenance procedures for the operations organizations prior to equipment turnover (CD 4). 
HNF-3192

Revision 0
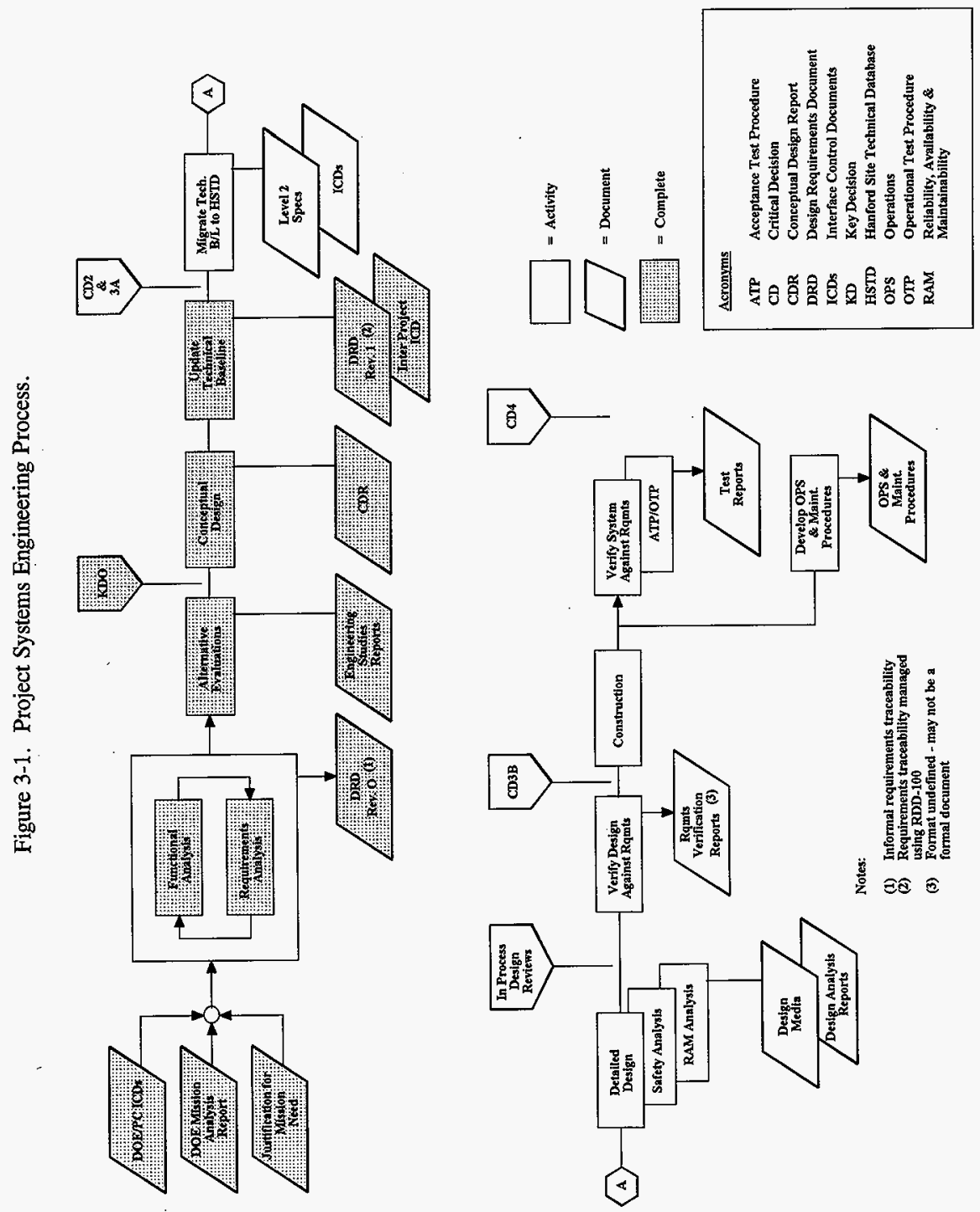
HNF-3192

Revision 0

\subsection{MAJOR PRODUCTS}

Project W-519 will develop systems engineering products to document the results of the project definition and design activities and to describe the future activities to verify the design satisfies requirements. The following provides a listing of the systems engineering documents contained in the TWRS SEMP with an explanation of the applicability to W-519, and where applicable, a description of the equivalent W-519 document. The project systems engineering documents have been selected based on the project grading described in Section 1.2.3.

Mission Analysis Report: Top level Project W-519 mission information is included in the TWRS Phase 1 Privatization Infrastructure Project Mission Analysis Report (Hoertkorn 1997). This document was prepared in keeping with the guidance of the TWRS SEMP Revision 0 (Peck 1996) that called for a mission analysis for projects that were not defined using a top down systems engineering process. The Project Justification for Mission Need defines the overall purpose of the project.

Operations and maintenance concept: The infrastructure SSCs are extensions of exiting Hanford systems and will be operated and maintained in accordance with existing philosophies and procedures. Operations and maintenance procedures will be developed for the new SSCs as required to ensure the operations and maintenance data is current and complete.

Functions and Requirements/Specifications/Project Design Criteria: Project W-519 has a set of approved Design Requirements Documents defining the project requirements. The contents of the DRDs will be entered into the HSTD and Level 2 specifications equivalent to the DRDs with full requirements traceability will be generated. The current DRDs are as follows:

- TWRS Privatization Phase 1, Site Development Design Requirements Document (Shord 1997)

- Design Requirements Document for the Phase 1 Privatization Electrical Power System (Singh 1997)

- TWRS Privatization Phase 1 Raw and Potable Water Supply Systems (Parazin 1996a)

- TWRS Privatization Phase I Liquid Effluent Transfer Systems (Parazin 1996b)

Alternative Analysis and Selection/Trade Studies: The project architecture was selected based on the engineering studies conducted for the conceptual design. These studies were based on the Design Requirements Documents. The studies performed include the following:

- TWRS Privatization Phase 1, Site Development Engineering Study (Shord 1996a) 
HNF-3192

Revision 0

- Engineering Study for the Phase 1 Privatization Facilities Electrical Power (Singh 1996)

- TWRS Privatization Phase 1 Raw and Potable Water Service Engineering Study (Shord 1996b)

- $\quad$ TWRS Privatization Phase 1 Liquid Effluent Transfer Systems Engineering Study (Parazin 1996c)

Decision Documents: Project level decisions have been documented in the Conceptual Design Reports. No further project level decisions have been identified at this time. Design decisions will be documented through the design analysis reports.

Interface Control Documents/Diagrams: The project has physical interfaces with three different groups: the other TWRS projects, other PHMC major facilities, and the private contractors. For interfaces with the other TWRS projects, W-519 has developed the Interface Control Document for TWRS Privatization Phase 1 Infrastructure Support Project W-519 (Parazin 1998b) documenting where the project interfaces with other tank farm projects. The interfaces with the other PHMC major facilities are documented in the Conceptual Design Reports and detailed design media. The Design Authorities for this project are the interfacing major facility owners, which fulfills the integration requirement for design coordination between two systems. The interfaces with the Private Contractor (PC) are documented through a Privatization ICD. Functional and organizational interface control is described in Section 2.3 of this document.

\section{System Assessment/Evaluations: N/A}

Specialty Engineering Analysis Reports: The project will perform the necessary specialty engineering analysis to ensure the design satisfies the DRD specialty engineering requirements.

The planned analyses and related documentation include the following:

- Reliability, Availability and Maintainability

- Safety

Preliminary Safety Evaluation

Safety assessment

Unresolved Safety Question Screening

Fire Hazard Analysis

- Quality Assurance (NHC-QAPP-018) 
HNF-3192

Revision 0

Design Optimization: The project has performed design optimization and documented the results in the engineering studies and conceptual design reports.

Test and Evaluation: Evaluation of the design will be performed as part of the design verification process described in the PEP Section 5.7 (Parazin 1998). The project test activities will be documented in Acceptance Test Procedures developed by the design agent and Operational Test Procedures developed by the respective PHMC operating contractor.

Integrated Logistics: In order to support installation, the project will purchase construction spares for the new systems. The project will provide for the development of operations and maintenance procedures. The facility owners are responsible for the remainder of the logistics support activities including sparing, any required operations training, etc. This agreement will be documented in a memorandum of agreement.

\subsection{ROLES AND RESPONSIBILITIES}

Roles and responsibilities for the systems engineering products are defined in the Tank Waste Remediation System Privatization Phase I Infrastructure Project W-519 Project Execution Plan (Parazin 1998) Table 3-1. 
HNF-3192

Revision 0

This page intentionally left blank. 
HNF-3192

Revision 0

\subsection{REFERENCES}

Acree, C. D., 1998, Tank Waste Remediation System Mission Analysis, HNF-SD-WM-MAR-008, Rev. 3, January 1998, Lockheed Martin Hanford Company, Richland, Washington.

BNFL, 1998, Tank Waste Remediation System Privatization Project Interface Control Document, BNFL-5193, BNFL, Inc., Richland, Washington

DOE, 1996, Life Cycle Asset Management, DOE Order 430.1, U.S. Department of Energy, Washington, D.C.

Hoertkorn, T. R., 1997, TWRS Phase 1 Privatization Infrastructure Project Mission Analysis Report, No Number, Department of Energy, Richland Operations, Richland, Washington.

Kinzer, J. 1997, Tank Waste Remediation System (TWRS) Systems Engineering Management Policy, (Letter \#97-MSD-193 to President, Fluor Daniel Hanford Company, Richland, Washington, April 9, 1997) U.S. Department of Energy, Richland Operations Office, Richland, Washington

LMHC, 1997, Tank Waste Administration, HNF-IP-0842, prepared by Lockheed Martin Hanford Company for Fluor Daniel Hanford, Inc., Richland, Washington.

National Environmental Policy Act of 1969, Public Law, 42 USC 4321 et seq.

Parazin, R. J., 1996a, Design Requirements Document, TWRS Privatization Phase 1 Raw and Potable Water Supply Systems, WHC-SD-WM-DRD-015, Rev. 0, Westinghouse Hanford Company, Richland, Washington.

Parazin, R. J., 1996b, Design Requirements Document, TWRS Privatization Phase 1 Liquid Effluent Transfer Systems, WHC-SD-WM-DRD-014, Rev. 0, Westinghouse Hanford Company, Richland Washington

Parazin, R. J., 1996c, TWRS Privatization Phase 1 Liquid Effluent Transfer Systems Engineering Study, WHC-SD-TWR-ES-396 Rev. 0, Westinghouse Hanford Company, Richland, Washington.

Parazin, R. J., 1998a, TWRS Privatization Phase I Infrastructure Project W-519 Project Execution Plan, HNF-2811, dated August 1998, Numatec Hanford Company, Richland, Washington. 
HNF-3192

Revision 0

Parazin, R. J., 1998b, Interface Control Document for Tank Waste Remediation System Privatization Phase 1 Infrastructure Support Project W-519, HNF-2588, Rev. 0, Numatec Hanford Company, Richland, Washington.

Parazin, R. J., 1998c TWRS Privatization Phase I Infrastructure Project Configuration Management Implementation Plan, HNF-3046, dated August 1998, Numatec Hanford Company, Richland, Washington.

Peck, L. G., 1996, Tank Waste Remediation System Systems Engineering Management Plan, WHC-SD-WM-SEMP-002, Rev. 0, Westinghouse Hanford Company, Richland Washington.

Peck, L. G., 1998, Tank Waste Remediation System Systems Engineering Management Plan, HNF-SD-WM-SEMP-002, Rev. 1, Lockheed Martin Hanford Company, Richland Washington.

Shord, A. L., 1996a, TWRS Privatization Phase 1, Site Development Engineering Study, WHC-SD-TWR-ES-003, Rev. 0, Westinghouse Hanford Company, Richland, Washington.

Shord, A. L., 1996b, TWRS Privatization Phase 1 Raw and Potable Water Service Engineering Study, WHC-SD-TWR-ES-002 Rev. 0, Westinghouse Hanford Company, Richland, Washington

Shord, A. L., 1997, TWRS Privatization Phase 1, Site Development Design Requirements Document, WHC-SD-TWR-DRD-013 Rev. 1, Numatec Hanford Corporation, Richland, Washington.

Singh, G., 1996, Engineering Study for the Phase 1 Privatization Facilities Electrical Power WHC-SD-WM-ES-393, Rev. 0, Westinghouse Hanford Company, Richland, Washington

Singh, G., 1997, Design Requirements Document for the Phase 1 Privatization Electrical Power System, WHC-SD-WM-DRD-011, Rev 1, Numatec Hanford Company, Richland Washington.

Vann, J. M., 1998, TWRS Configuration Management Plan, HNF-1900, Rev. 0, Lockheed Martin Hanford Company, Richland Washington

Zimmerman, B. D., 1997, TWRS Technical Decision Status Summary, Lockheed Martin Hanford Company, Richland, Washington. 
HNF-3192

Revision 0

\section{APPENDIX A}

\section{W-519 SYSTEMS ENGINEERING GRADED RISK AREAS/COMPLEXITY FACTORS}


HNF-3192

Revision 0

This page intentionally left blank. 
HNF-3192

Revision 0

APPENDIX A

\section{W-519 SYSTEMS ENGINEERING GRADED RISK AREAS/COMPLEXITY FACTORS}

Table A-1. W-519 Electrical System Systems Engineering Graded Risk Areas/Complexity Factors.

\begin{tabular}{|c|c|c|}
\hline Risk/complexity factors & Risk & Rationale* \\
\hline Technology & Low & Commercial off-the-shelf equipment \\
\hline Time & Low & Ample time to perform work \\
\hline Interfaces & High & $\begin{array}{l}\text { Potential major impact to operations and } \\
\text { other contractors. }\end{array}$ \\
\hline Number of Key Participants & High & $\begin{array}{l}\text { Bonneville Power Administration, } \\
\text { DynCorp, PC, Project }\end{array}$ \\
\hline Contractor Capabilities & Low & Proven track record \\
\hline $\begin{array}{l}\text { Magnitude and type of } \\
\text { environmental contamination }\end{array}$ & Low & N/A \\
\hline Regulatory Involvement & Low & None \\
\hline NEPA, Permits or Licensing & Low & TWRS ROD and no additional permitting \\
\hline $\begin{array}{l}\text { Number of locations/Site } \\
\text { Ownership/Site } \\
\text { Improvements Access }\end{array}$ & Low & $\begin{array}{l}1 \text { site, No infrastructure or improvements } \\
\text { required }\end{array}$ \\
\hline $\begin{array}{l}\text { Labor Skills, Availability, } \\
\text { Staff build up and } \\
\text { Productivity }\end{array}$ & Moderate & $\begin{array}{l}\text { High voltage work requires special labor } \\
\text { skills and qualifications }\end{array}$ \\
\hline Quality Requirements & Low & \\
\hline Funding & Moderate & 2-3 years for design/construction/startup \\
\hline Political visibility & Low & \\
\hline Cost Sharing & Low & . \\
\hline Public Involvement & Low & Tribal nations \\
\hline Overall Complexity & Low & \\
\hline
\end{tabular}

NEPA = National Environmental Policy Act of 1969

$\mathrm{PC}=$ Privatization Contractor

ROD $=$ Record of Decision

TWRS = Tank Waste Remediation System

*Risk/Complexity factor evaluation criteria used to develop rationale contained in Draft TWRS Systems Engineering Grading Guidelines, Table 5.1 
Table A-2. W-519 Liquid Effluent Transfer System Systems Engineering Graded Risk Areas/Complexity Factors.

\begin{tabular}{|c|c|c|}
\hline Risk/complexity factors & Risk & Rationale* \\
\hline Technology & Low & $\begin{array}{l}\text { Common/off-the-shelf technology } \\
\text { Civil/conventional construction }\end{array}$ \\
\hline Time & Low & Ample time to perform work \\
\hline Interfaces & High & $\begin{array}{l}\text { Potential major impacts on site operations, } \\
\text { and other contractors }\end{array}$ \\
\hline Number of Key Participants & High & WMH, Project, Ecology, PC \\
\hline Contractor Capabilities & Low & Proven track record \\
\hline $\begin{array}{l}\text { Magnitude and type of } \\
\text { environmental contamination }\end{array}$ & Low & $\begin{array}{l}\text { Hazardous or low-level waste, fully } \\
\text { characterized }\end{array}$ \\
\hline Regulatory Involvement & Moderate & WAC \\
\hline NEPA, Permits or Licensing & Low & TWRS ROD and no additional permitting \\
\hline $\begin{array}{l}\text { Number of locations/Site } \\
\text { Ownership/Site } \\
\text { Improvements Access }\end{array}$ & Low & 1 \\
\hline $\begin{array}{l}\text { Labor Skills, Availability, } \\
\text { Staff build up and } \\
\text { Productivity }\end{array}$ & Low & $\begin{array}{l}\text { No special skill requirements, staff readily } \\
\text { available, }\end{array}$ \\
\hline Quality Requirements & Low & \\
\hline Funding & Moderate & $\begin{array}{l}2-3 \text { year duration, other line item project } \\
\text { size }\end{array}$ \\
\hline Political visibility & Low & none \\
\hline Cost Sharing & Low & none \\
\hline Public Involvement & Low & Tribal nations \\
\hline Overall Complexity & Low & \\
\hline
\end{tabular}

NEPA = National Environmental Policy Act of 1969

$\mathrm{PC}=$ Privatization Contractor

ROD $=$ Record of Decision

TWRS $=$ Tank Waste Remediation System

WAC $=$ Washington Administrative Code

$\mathrm{WMH}=$ Waste Management Federal Services of Hanford, Inc.

*Risk/Complexity factor evaluation criteria used to develop rationale contained in Draft TWRS Systems Engineering Grading Guidelines, Table 5.1. 
Table A-3. W-519 Raw and Potable Water Supply System Systems Engineering Graded Risk Areas/Complexity Factors.

\begin{tabular}{|c|c|c|}
\hline Risk/complexity Factors & Risk & Rationale* \\
\hline Technology & Low & $\begin{array}{l}\text { Common/off-the-shelf technology } \\
\text { Civil/conventional construction }\end{array}$ \\
\hline Time & Low & Ample time to perform work \\
\hline Interfaces & High & $\begin{array}{l}\text { Potential major impacts on site } \\
\text { operations, and other contractors }\end{array}$ \\
\hline Number of Key Participants & Moderate & PC, DynCorp, Project \\
\hline Contractor Capabilities & Low & Proven track record \\
\hline $\begin{array}{l}\text { Magnitude and type of } \\
\text { environmental contamination }\end{array}$ & Low & $\begin{array}{l}\text { Hazardous or low-level waste, fully } \\
\text { characterized }\end{array}$ \\
\hline Regulatory Involvement & Moderate & WAC \\
\hline NEPA, Permits or Licensing & Low & $\begin{array}{l}\text { TWRS ROD and no additional } \\
\text { permitting }\end{array}$ \\
\hline $\begin{array}{l}\text { Number of locations/Site } \\
\text { Ownership/Site } \\
\text { Improvements Access }\end{array}$ & Low & 1 \\
\hline $\begin{array}{l}\text { Labor Skills, Availability, } \\
\text { Staff build up and } \\
\text { Productivity }\end{array}$ & Low & $\begin{array}{l}\text { No special skill requirements, staff } \\
\text { readily available, }\end{array}$ \\
\hline Quality Requirements & Low & \\
\hline Funding & Low & 1 year duration \\
\hline Political visibility & Low & none \\
\hline Cost Sharing & Low & none \\
\hline Public Involvement & Low & Tribal nations \\
\hline Overall Complexity & Low & \\
\hline
\end{tabular}

NEPA = National Environmental Policy Act of 1969

$\mathrm{PC}=$ Privatization Contractor

ROD $=$ Record of Decision

WAC $=$ Washington Administrative Code

*Risk/Complexity factor evaluation criteria used to develop rationale contained in Draft TWRS Systems Engineering Grading Guidelines, Table 5.1 
HNF-3192

Revision 0

This page intentionally left blank. 
HNF-3192

Revision 0

\section{APPENDIX B}

\section{GRADING OF MAJOR PRODUCTS BASED ON RISK/COMPLEXITY FACTORS}


HNF-3192

Revision 0

This page intentionally left blank.

B-2 
HNF-3192

Revision 0 .

\section{APPENDIX B}

\section{GRADING OF MAJOR PRODUCTS BASED ON RISK/COMPLEXITY FACTORS}

As described in Section 1.2.3 of this document the following table defines the planned W-519 System Engineering product list using the grading results from Appendix A, and Draft TWRS Systems Engineering Grading Guidelines, Table 5.2 Systems Engineering Products/Process list. A "yes" or "no" signifies the projects plan on whether or not the product is required.

Table B-1. Major Products Based on Risk/Complexity Factors. (2 Sheets)

\begin{tabular}{|l|c|c|c|}
\hline \multicolumn{1}{|c|}{$\begin{array}{c}\text { Systems engineering } \\
\text { process/product }\end{array}$} & Electrical & Liquid effluent & $\begin{array}{c}\text { Raw and } \\
\text { potable water }\end{array}$ \\
\hline Mission Analysis Report & Yes $^{1}$ & Yes $^{1}$ & Yes \\
\hline Project Design Criteria & No & No & No \\
\hline O\&M Concept & No & No & No \\
\hline Systems Engineering Plans & Yes & Yes & Yes \\
\hline Risk Management Process & Yes & Yes & Yes \\
\hline Decision Management Process & Yes & Yes & Yes \\
\hline Decision Documents & As Required & As Required & As Required \\
\hline Interface Control Documents & Yes & Yes & Yes \\
\hline Interface Control Drawings & Yes & Yes & Yes \\
\hline $\begin{array}{l}\text { Configuration Management } \\
\text { Process }\end{array}$ & Yes & Yes & Yes \\
\hline Project Technical Reviews & Yes & Yes & Yes \\
\hline $\begin{array}{l}\text { Traceability of Technical } \\
\text { Requirements }\end{array}$ & Yes & Yes & Yes \\
\hline Functional Flow Block Diagrams & No & No & No \\
\hline Requirements Analysis Reports & No & No & No \\
\hline $\begin{array}{l}\text { Alternative Generation \& } \\
\text { Analysis Reports }\end{array}$ & Yes & Yes & Yes \\
\hline Level 2 Specifications & & & Yes \\
\hline
\end{tabular}


HNF-3192

Revision 0

Table B-1. Major Products Based on Risk/Complexity Factors. (2 Sheets)

\begin{tabular}{|l|c|c|c|}
\hline \multicolumn{1}{|c|}{$\begin{array}{c}\text { Systems engineering } \\
\text { process/product }\end{array}$} & Electrical & Liquid effluent & $\begin{array}{c}\text { Raw and } \\
\text { potable water }\end{array}$ \\
\hline $\begin{array}{l}\text { Requirements Verification } \\
\text { Reports }\end{array}$ & Yes & Yes & Yes \\
\hline Test Procedures & Yes & Yes & Yes \\
\hline Test Reports & Yes & Yes & Yes \\
\hline $\begin{array}{l}\text { Technical Performance } \\
\text { Measurement }\end{array}$ & No & No & No \\
\hline System Analysis Reports & No & No & No \\
\hline Construction Specifications & No & Yes & Yes \\
\hline Trade Study Reports & Yes ${ }^{2}$ & Yes & Yes \\
\hline Master Equipment Lists & Yes & Yes & Yes \\
\hline Design Analysis Reports & Yes & Yes & Yes \\
\hline Procurement Specifications & Yes & Yes & Yes \\
\hline As-Built Drawings & Yes & Yes & Yes \\
\hline Operations Manuals/Procedures & Yes & Yes & Yes \\
\hline $\begin{array}{l}\text { Specialty Engineering Analysis } \\
\text { Report }\end{array}$ & Yes & Yes & Yes \\
\hline Safety Equipment List & Yes & Yes & Yes \\
\hline Maintenance Manuals/Procedures & Yes & Yes & Yes \\
\hline Training Certification & No & No & No \\
\hline Licenses and Permits & No & No & No \\
\hline FSAR & No & No & No \\
\hline
\end{tabular}

DOE $=$ U.S. Department of Energy

FSAR $=$ Facility Safety Analysis Report

$O \& M=$ Operations and Maintenance

SEMP = Systems Engineering Management Plan

TWRS $=$ Tank Waste Remediation System

${ }^{1}$ Developed by DOE before release of TWRS SEMP Rev. 1

${ }^{2}$ Included in Conceptual Design Reports. 
HNF-3192

Revision 0

\section{APPENDIX C}

\section{INFRASTRUCTURE PROGRAM RISK MANAGEMENT IMPLEMENTATION PLAN}


HNF-3192

Revision 0

This page intentionally left blank. 
HNF-3192

Revision 0

\section{APPENDIX C}

\section{INFRASTRUCTURE PROGRAM RISK MANAGEMENT IMPLEMENTATION PLAN}

The W-519 Risk Management Process steps are described below and shown graphically in Figure C-1. The Project performs these activities with support from the Tank Waste Retrieval (TWR) Risk Analysis staff to facilitate the process.

Identify Risk Elements. Risk elements (tasks) are analyzed to identify areas of variation and uncertainty in both budget and schedule. This exercise is used to uncover potential risk factors.

Identify Risks. The risk factors identified in the previous step are screened to identify risks to the program.

Develop Risk Impacts. For each of the identified risks, likelihood of occurrence is estimated, and consequence range is determined. Variable cost elements that will occur are separated from variable cost elements that are uncertain to occur. In addition, the uncertain elements are further assessed to filter out those items which are outside the scope of the work or are below the threshold of credibility or cost impact. These items are recorded.

Evaluate Risk. Using the likelihood and consequence distribution data developed above as inputs, a probability of success curve is developed using a Monte Carlo technique. In addition, higher risk impact elements are identified for further analysis.

Identify Mitigation Action. For each risk, a handling option is identified. For the handling options that require mitigation, a mitigation plan is developed. Steps are identified, responsibilities are established, costs are determined and closure criteria are developed.

Develop Residual Risk Impacts. After identification of mitigation plans, the risks are reevaluated to determine the remaining or residual risk. Likelihood of occurrence is reestimated, and consequence range is re-determined.

Prioritize Actions. The return on investment (ROI) for an individual mitigation action can now be calculated using the pre and post mitigation impacts and the cost of the mitigation action. The actions are then prioritized based upon the ROI.

Implement Actions. The prioritized list is integrated with other factors such as management sensitivities, political impacts, and regulatory requirements to determine which actions are to be implemented and which are to be denied or deferred. The selected actions are integrated into the multi-year work plan and are handled as part of the planned work. 
HNF-3192

\section{Revision 0}

Monitor Risk Actions. Status of risk mitigation actions will be reported during periodic budget reviews. In addition to existing reporting process requirements, each action will be color coded to indicate how well it is being implemented.

Close Risk Actions. A risk action can be closed in one of two ways, either upon completion of closure criteria or upon elimination of the risk. In either case, closure recommendation will be documented and reported at the budget review for management concurrence. 
Figure C-1. Risk Management Implementation Diagram.

Classify Tasks

- Fixed cost (Money \& Time); Variable cost (Money \& Time);

Uncertain cost (Money \& Time); Showstoppers (Money \& Time)

Collect Risks From:

- TBR, CEIS; Studies; Team Meetings; Engineering documents; MYPP

Determine responsibilities

Determine Range (Min., Most Likely, Max) of consequences for:

- Variable elements; Uncertain elements

Determine Range of Probabilities for:

- Uncertain elements

Input data

Perform analyses

Generate report

Develop Critical Risk, List

Develop risk mitigation actions:

- Identify Steps; Assign responsibility; Determine cost; Establish closure

For Residual Risk

Determine Range (Min, Most Likely, Max) of consequences for:

- Variable elements; Uncertain elements

Determine Range of Probabilities for:

- Uncertain elements

Determine ROI for each action

Rank action

Update report

Implement Action Plans

- Select actions to fund

- Add to MYPP

Assess Risk Status

Report Status

Adjust action plan (as required)

When closure criteria is met:

- Close action

- Record Closure

- Prepare \& distribute closure report

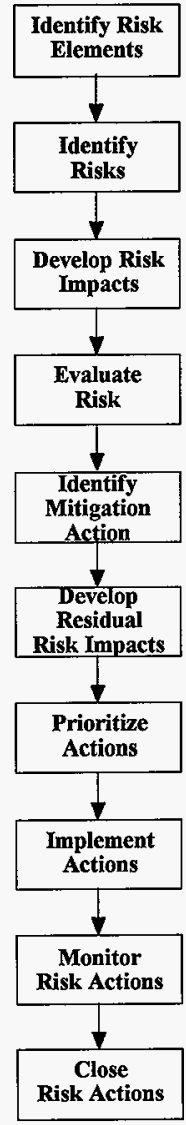

CEIS $=$ Cost estimating input sheet

MYPP = Multi-year program plan

ROI $=$ Return on investment

$\mathrm{TBR}=$ Technical Basis Review . 
HNF-3192

Revision 0

This page intentionally left blank. 


\section{DISTRIBUTION SHEET}

\begin{tabular}{|c|c|c|c|c|c|}
\hline \multirow{2}{*}{$\begin{array}{l}\text { To } \\
\text { Distribution }\end{array}$} & \multirow{2}{*}{\multicolumn{3}{|c|}{$\begin{array}{l}\text { From } \\
\text { P. S. Schaus, LMHC }\end{array}$}} & \multicolumn{2}{|l|}{ Page 1 of 1} \\
\hline & & & & \multicolumn{2}{|c|}{ Date $8 / 17 / 98$} \\
\hline \multicolumn{4}{|l|}{ Project Title/Work Order } & \multicolumn{2}{|c|}{ EDT No. 161498} \\
\hline \multicolumn{4}{|c|}{$\begin{array}{l}\text { Tank Waste Remediation Systems Privatization Phase } 1 \\
\text { Infrastructure Project Systems Engineering Implementaion Plan, } \\
\text { HNF-3192, Rev. } 0\end{array}$} & \multicolumn{2}{|l|}{ ECN No. } \\
\hline Name & MSIN & $\begin{array}{l}\text { Text } \\
\text { With All } \\
\text { Attach. }\end{array}$ & Text Only & $\begin{array}{l}\text { Attach./ } \\
\text { Appendix } \\
\text { Only }\end{array}$ & $\begin{array}{l}\text { EDT/ECN } \\
\text { Only }\end{array}$ \\
\hline
\end{tabular}

Central Files

DOE Reading Room

DIMC

S. K. Baker

H. L. Boston

D. L. Fort

P. A. Haine

B. J. Hendel

T. R. Hoertkorn (DOE)

S. S. Lowe

S. M. O'Toole

R. J. Parazin

L. G. Peck

G. R. Porter

R. W. Root

H. Rossi

P. S. Schaus

G. Singh

W. T. Thompson

$\begin{array}{ll}\text { B1-07 } & X \\ \text { H2-53 } & X \\ \text { R1-41 } & X\end{array}$

H5-49 X

R2-53 X

R3-47 $X$

R3-47 $X$

$B 1-45 \quad X$

A2-22 $X$

H6-06

R2-89

R3-47

H7 -06

R3-47

R2-53

B1- -45

R2-89

R3-47

G3-21 $X$ 